\title{
Weed-Crop Competition in Pigeon Peas in Puerto Rico $^{1}$
}

\author{
Manuel Diaz-Rivera, Paul R. Hepperly, Guillermo Riveros and \\ Luis Almodóvar-Vega ${ }^{2}$
}

\begin{abstract}
Kaki and 2B-Bushy pigeon peas were grown in the southern plains of Puerto Rico, in four spatial arrangements with six intervals of weed competition during two growing seasons to determine the influence of weed competition on crop growth, development and yield. In both growing seasons, Cleome gynandra, Amaranthus dubius, Echinochloa colona, Leptochloa filiformis, and Digitaria sanguinalis were the dominant weeds. C. gynandra and E. colona dominated the early weed flora until approximately $\mathbf{4 0}$ days after pigeon pea emergence. Later, weed flora was dominated by $L$. filiformis, $D$. sanguinalis, and $A$. dubius. The presence of weeds during early growth stages reduced initial crop growth and delayed differentiation including flowering of the two pigeon pea cultivars. Elimination of weeds at or before 21 to 28 days after pigeon pea emergence and thereafter, generally resulted in the recovery of pigeon pea plants and prevented measurable losses in final yield. The critical period for removing weeds in pigeon peas appeared to vary between the pigeon pea cultivars and between the two growing seasons. In the May 6 planting, pigeon pea yields were reduced after 28 and 21 days of early competition for Kaki and 2B-Bushy, respectively. In the July 1 planting, however, losses occurred at 21 and 14 days of weed competition for the two respective cultivars. No differences were found in weed numbers or yield between the two cultivars or among spatial arrangements in either planting season. However, weed number and yield were greater during the first planting season compared with those of the second.

Planting pigeon peas under short photoperiods accelerated vegetative growth, shortened the total cropping cycle, and resulted in reduced yield and total growth for both cultivars. Losses from early weed competition occurred earlier under the short-day planting than those under the long-day planting.
\end{abstract}

\section{INTRODUCTION}

The pigeon pea, [Cajanus cajan (L.) Millsp.], is one of the most important food crops produced commercially in Puerto Rico. In 1979-80, production exceeded 5.5 million kilograms, with a farm value of about $\$ 7$ million. ${ }^{3}$ From 1975 to 1980 production increased $31 \%{ }^{4}$ Nevertheless, local demand greatly exceeds production and substantial quantities of pigeon peas are imported each year.

Pigeon pea farmers in Puerto Rico exert considerable effort in controlling weeds. Manual removal of weeds is costly since normal produc-

${ }^{1}$ Manuscript submitted to Editorial Board January 25, 1984.

${ }^{2}$ First and third authors are former members of the Department of Crop Protection, College of Agricultural Science, University of Puerto Rico Mayaguez Campus 00709. Second and fourth are Associate Professors in the same department.

${ }^{3}$ Commonwealth of Puerto Rico, 1981. Facts and Figures on Puerto Rico's Agriculture 1978/79-1979/80. Dept. of Agriculture, Office of Agricultural Statistics, Santurce.

${ }^{4}$ Commonwealth of Puerto Rico, 1976. Facts and Figures on Puerto Rico's Agriculture 1975/76. Dept. of Agriculture, Office of Agricultural Statistics, Santurce. 
tion requires several passes. Potentially, use of herbicides can improve weed control in pigeon peas and reduce production costs. Prometryn and metribuzin are two preemergent herbicides registered for use on pigeon peas in Puerto Rico. Farmers have been slow to use herbicides because they often lack proper equipment and the experience and knowledge for their proper use. Variable soils and rainfall conditions have caused failures even when herbicides were properly applied. Leaching of prometryn and metribuzin under heavy rainfall and in sandy areas can result in marked crop damage. ${ }^{5}$

To manage more effectively weeds in pigeon peas, exact information on weed losses and timing of control measures will be helpful. The following weed-crop competition experiments were conducted to determine the extent of losses due to weeds in the southern coastal plain of Puerto Rico, the effects of planting season, cultivar and spatial design on weed competition and critical times for weed removal to control crop losses from weeds.

\section{MATERIALS AND METHODS}

Experiments were conducted at the Fortuna Research Center of the University of Puerto Rico College of Agricultural Sciences Experiment Station in Juana Díaz, Puerto Rico, during the 1981-82 production season. The soil in the experimental area was a sandy loam Mollisol of the San Antón series with a pH of approximately 6.5. At two planting dates (May 6 and July 1) pigeon peas were established in a split-split plot design with three replications. The two pigeon pea cultivars ('Kaki' and ' $2 \mathrm{~B}$-Bushy') were the main treatments at each planting date. The four spatial arrangements were the subtreatments. Six weed-competition intervals were the sub-subtreatments. Four plant arrangements were used with two row spacings (91.4 and $60.9 \mathrm{~cm}$ on center). At 20.3 and $30.5 \mathrm{~cm}$ intrarow plant spacings a 57,710 plants/ha population was established on rows 91.4 and $60.9 \mathrm{~cm}$ on center, respectively. At the 30.5 and $45.7 \mathrm{~cm}$ intrarow plant spacings a population of 35,806 plants /ha was used for the two respective row spacings.

Six intervals of weed competition were established by permitting either $14,21,28,35$ or 42 days of initial weed presence starting from the time of pigeon pea emergence, and then continuously removing weeds thereafter until pigeon pea harvest, and by leaving pigeon peas completely unweeded (full season check). The sub-subtreatment plots were $3.6 \mathrm{~m}$ wide by $6.0 \mathrm{~m}$ long. Plots consisted of 6 and 4 rows 60.9 and $91.4 \mathrm{~cm}$ on center, respectively.

\footnotetext{
${ }^{5}$ Thompson, W. T., 1979. Agricultural Chemical Book. II. Herbicides. Thompson Publications, Fresno, California.
} 
Land was prepared by moldboard plowing and two passes by a heavy tandem disc. Seeding was done by hand. Approximately 20 seeds were planted per meter row, and emerging plants were thinned to the desired densities 1 week following emergence. To stimulate uniform crop and weed emergence sprinkler irrigation was applied following seeding. Irrigation was applied from flowering through pod fill as needed to help stimulate high yield by eliminating drought stress.

In nonweeded sub-subtreatments, weeds were sampled at each planting for each cultivar and spatial arrangement. Weed sampling started 14 days after planting and was followed at 1-week intervals thereafter for 49 days. In sampling a $50 \times 25 \mathrm{~cm}$ wooden rectangular grid was randomly tossed four times into the center of the sub-subtreatment plots. Weeds within the grid were harvested and bulked in labeled plastic bags for laboratory analysis. In the laboratory, weeds were separated according to species and then counted and weighed.

Weather data on daily precipitation during the two planting seasons was obtained from the Fortuna Research Center Weather Station Record (fig. 1).

Crop development data on height, branching, flowering, and yield of pigeon peas were taken. To follow growth and development of pigeon peas, three random plants were selected in the center rows of each subsubtreatment plot and marked. Height and branching data were taken on marked plants at 1-week intervals for 50 days from pigeon pea emergence, and at a 2-week interval thereafter until harvest. Flowering data are based on counts of plants with one or more flowers in one center row of each sub-subtreatment plot on a weekly basis starting at first flower and continuing until all plants showed flowering. Yield data are based on the harvest of 3 or 2 center rows from the 60.9 and $91.4 \mathrm{~cm}$ spacings, respectively. In each sub-subtreatment plot, area harvested was $10.8{ }^{2}$ Pigeon peas were harvested in full green and yellow pod stages at a weekly interval. Yields are expressed as kilograms of fresh full pods per hectare surface area harvested.

\section{RESULTS}

\section{WEEDS}

There was no statistical difference in weed development between 2BBushy and Kaki pigeon peas based on fresh weights 49 days after planting (table 1). During both planting seasons, spatial arrangements did not differ in weed growth. Weed weights were lower in the July 1 planting than in the May 6 planting. Figure 2 presents weed fresh weights from 21 to 49 days after planting. Lower weed fresh weight in the July planting appears to be due to lower precipitation in that period compared to that 


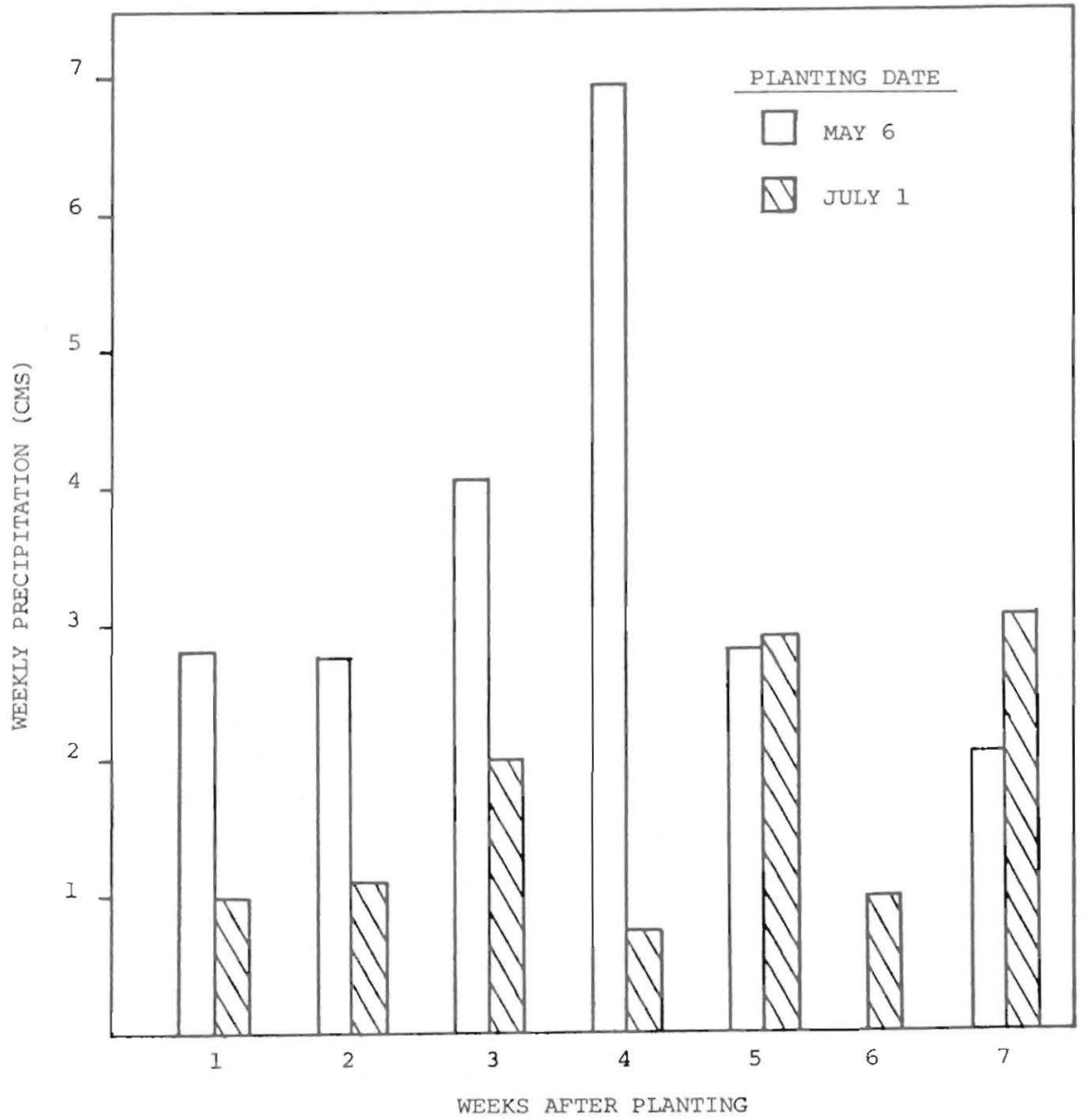

FIG. 1.-Precipitation patterns during the early development of two plantings of Kaki and $2 \mathrm{~B}$-Bushy pigeon peas during two planting seasons in Juana Díaz, Puerto Rico.

of the May 6 planting (fig. 1). Mean weekly precipitation during the first 2 months after pigeon pea planting was less than $2 \mathrm{~cm}$ for the July planting and over $3 \mathrm{~cm}$ for the May planting.

In both growing seasons, Cleome gynandra, Amaranthus dubius, Echinocloa colona, Leptochloa filiformis, and Digitaria sanguinalis were the dominant weeds. Cleome gynandra and E. colona predominated in the early weed flora until approximately 40 days after pigeon pea emergence. After that time, weed flora was dominated by L. filiformis, D. sanguinalis, and $A$. dubius in that order of appearance. 
TABLE 1.-Weed fresh weights 49 days after pigeon pea planting for two pigeon pea cultivars under four spatial arrangements when pigeon peas were grown in two planting seasons of Juana Diaz, Puerto Rico in 1981

\begin{tabular}{ccccc}
\hline & \multicolumn{4}{c}{ Weed fresh weights (kg/ha) } \\
\cline { 2 - 5 } $\begin{array}{c}\text { Row } \\
\text { spacing }\end{array}$ & \multicolumn{4}{c}{ Planting date } \\
\cline { 2 - 5 } & \multicolumn{3}{c}{ May 6 July 1 } \\
\cline { 2 - 5 } & 35,806 & 57,710 & 35,806 & 57,710 \\
91.4 & 38,310 & 39,123 & 16,846 & 21,700 \\
60.6 & 30,601 & 35,911 & 22,171 & 17,462 \\
& 33,181 & 27,423 & 23,232 & 19,606 \\
91.4 & 35,085 & 37,118 & 20,447 & 19,778 \\
\hline
\end{tabular}

${ }^{1}$ There were no statistical differences between cultivars nor between the spatial arrangements.

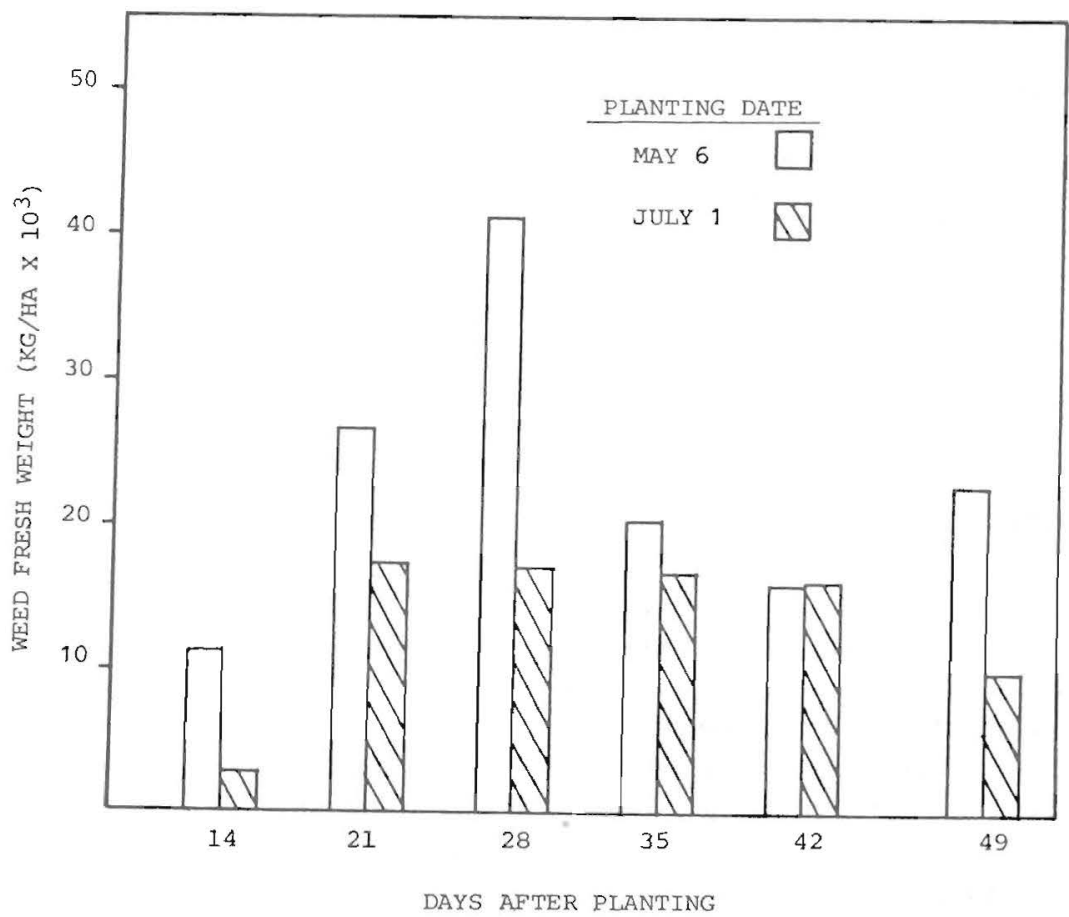

FIG. 2.-Comparative weed fresh yields in May 6 and July 1 plantings of Kaki and 2BBushy pigeon peas in Juana Díaz, Puerto Rico. 


\section{Crop development}

Early and full season weed competition appeared to have a great influence over morphological development in both pigeon pea cultivars at both early and later stages of growth cycles for both planting seasons. Measurements of early flowering, length of primary branches and plant nodes at 50 days showed high positive correlation with yield (table 2). Lower positive correlations were found between plant height and yield. In competition with weeds, pigeon peas etiolate, producing few branches, but many nodes on the main stem. Final node number was negatively correlated with yield in our experiments. Early node number and early

TABLE 2.-Coefficients of linear correlation ( $r$ ) between growth measurements at 50 days after pigeon pea planting (initial) or at harvest (final), and yield

\begin{tabular}{|c|c|c|c|c|}
\hline \multirow{4}{*}{ Growth measurements } & \multicolumn{4}{|c|}{ Pigeon pea cultivars } \\
\hline & \multicolumn{2}{|c|}{ Kaki } & \multicolumn{2}{|c|}{ 2B-Bushy } \\
\hline & \multicolumn{4}{|c|}{ Planting date } \\
\hline & May 6 & July 1 & May 6 & July 1 \\
\hline Initial height & $0.37 \mathrm{NS}^{2}$ & $0.61 * *$ & $0.37 \mathrm{NS}$ & $0.66^{* *}$ \\
\hline Final height & $0.43 \mathrm{NS}$ & $0.38 \mathrm{NS}$ & $0.37 \mathrm{NS}$ & $0.66^{* *}$ \\
\hline Initial node number & $0.80^{* *}$ & $0.67^{* *}$ & $0.71^{* *}$ & $0.79 * *$ \\
\hline Final node number & $-0.68^{* *}$ & $-0.45^{*}$ & $-0.75^{* *}$ & $-0.56^{*}$ \\
\hline Initial primary branch No. & $0.71 * *$ & $0.71 *$ & $0.64^{* *}$ & $0.79 * *$ \\
\hline $\begin{array}{l}\text { Final length of the largest pri- } \\
\text { mary branch }\end{array}$ & $0.83^{* *}$ & $0.51 *$ & $0.73^{* *}$ & $0.74 * *$ \\
\hline Percentage flowering (early) & $0.62 * *$ & $0.70^{* *}$ & $0.79^{* *}$ & $0.78^{* *}$ \\
\hline
\end{tabular}

${ }^{1}$ Coefficients of linear correlation ( $\mathrm{r}$ ) are based on 18 degrees of freedom in the May 6 planting and 22 for the July 1 planting.

${ }^{2}$ For coefficients of linear correlation $(\mathrm{r})$ NS signifies no statistical significance at $\mathrm{P}=$ 0.05 ; * indicates statistical significance of the $\mathrm{r}$ value at $\mathbf{P}=0.05$; and ${ }^{* *}$ shows statistical significance at $\mathrm{P}=0.01$.

branch number may be a good character for predicting final plant yield and these were greatly influenced by early weed competition. Tables 3 and 4 show the influence of period of weed competition on early and late stage plant morphology. Depression of early growth can be noted after 21 days of early weed competition; it was marked with 28 or more days of competition with weeds. Compared with that of the May planting, July planted pigeon peas showed greater early development (table 3). There was little difference in early development of Kaki or 2B-Bushy at either planting season. Early weed competition had a noticeable effect in delaying flowering in both cultivars and in both planting seasons (fig. 3). Delayed flowering was associated with the period of early weed competition and was most marked for the July planting of 2B-Bushy. Although 
TABLE 3.-The influence of early weed competition periods on the initial growth and development ${ }^{1}$ of Kaki and $2 B$-Bushy pigeon peas in two planting seasons in Juana Diaz, Puerto Rico

\begin{tabular}{|c|c|c|c|c|c|c|c|c|c|c|c|c|}
\hline \multirow{4}{*}{$\begin{array}{c}\text { Duration } \\
\text { of weed } \\
\text { competition }\end{array}$} & \multicolumn{12}{|c|}{ Planting Date } \\
\hline & \multicolumn{6}{|c|}{ May 6} & \multicolumn{6}{|c|}{ July 1} \\
\hline & \multicolumn{2}{|c|}{ Plant height } & \multicolumn{2}{|c|}{$\begin{array}{l}\text { Primary } \\
\text { branches }\end{array}$} & \multicolumn{2}{|c|}{ Longest branch } & \multicolumn{2}{|c|}{ Plant height } & \multicolumn{2}{|c|}{$\begin{array}{l}\text { Primary } \\
\text { branches }\end{array}$} & \multicolumn{2}{|c|}{ Longest branch } \\
\hline & Kaki & $2 \mathrm{~B}-\mathrm{B}$ & Kaki & $2 \mathrm{~B}-\mathrm{B}$ & Kaki & $2 \mathrm{~B}-\mathrm{B}$ & Kaki & $2 \mathrm{~B}-\mathrm{B}$ & Kaki & $2 \mathrm{~B}-\mathrm{B}$ & Kaki & $2 \mathrm{~B}-\mathrm{B}$ \\
\hline Days & \multicolumn{2}{|c|}{$\mathrm{cm}$} & \multicolumn{2}{|c|}{ no. } & \multicolumn{2}{|c|}{$\mathrm{cm}$} & \multicolumn{2}{|c|}{$\mathrm{cm}$} & \multicolumn{2}{|c|}{ no. } & \multicolumn{2}{|c|}{$\mathrm{cm}$} \\
\hline 14 & 117.8 & 121.6 & 19.3 & 16.4 & 63.5 & 55.3 & 131.4 & 128.2 & 19.6 & 16.2 & 87.4 & 97.9 \\
\hline 21 & 109.2 & 111.0 & 17.5 & 14.8 & 50.2 & 51.3 & 125.5 & 123.6 & 18.6 & 15.5 & 75.3 & 92.5 \\
\hline 28 & 101.3 & 97.5 & 16.7 & 14.6 & 46.1 & 41.4 & 118.5 & 115.0 & 17.1 & 13.8 & 68.8 & 68.4 \\
\hline 35 & 95.6 & 94.4 & 12.9 & 12.4 & 29.5 & 35.7 & 103.6 & 101.0 & 14.5 & 13.4 & 46.4 & 53.4 \\
\hline 42 & 95.3 & 95.5 & 14.4 & 11.2 & 25.5 & 25.4 & 95.3 & 100.0 & 12.9 & 12.9 & 33.7 & 52.2 \\
\hline $\begin{array}{l}\text { Full } \\
\text { season }\end{array}$ & 95.7 & 100.5 & 6.9 & 7.0 & 16.4 & 21.7 & 84.1 & 95.2 & 4.6 & 5.4 & 10.8 & 30.9 \\
\hline
\end{tabular}

\footnotetext{
${ }^{1}$ Measurements were taken 50 days after planting. Means are based on 12 replications.
} 
TABLE 4.-Influence of early weed competition periods on final ${ }^{1}$ plant morphology of Kaki and $2 B$-Bushy pigeon peas in two planting seasons in Juana Diaz, Puerto Rico

\begin{tabular}{|c|c|c|c|c|c|c|c|c|c|c|c|c|}
\hline \multirow{4}{*}{$\begin{array}{c}\text { Duration } \\
\text { of weed } \\
\text { competition }\end{array}$} & \multicolumn{12}{|c|}{ Planting date } \\
\hline & \multicolumn{6}{|c|}{ May 6} & \multicolumn{6}{|c|}{ July 1} \\
\hline & \multicolumn{2}{|c|}{ Primary branches } & \multicolumn{2}{|c|}{ Longest branch } & \multicolumn{2}{|c|}{ Plant height } & \multicolumn{2}{|c|}{$\begin{array}{l}\text { Primary } \\
\text { branches }\end{array}$} & \multicolumn{2}{|c|}{ Longest branch } & \multicolumn{2}{|c|}{ Plant height } \\
\hline & Kaki & $2 \mathrm{~B}-\mathrm{B}$ & Kaki & 2B-B & Kaki & $2 \mathrm{~B}-\mathrm{B}$ & Kaki & $2 \mathrm{~B}-\mathrm{B}$ & Kaki & $2 \mathrm{~B}-\mathrm{B}$ & Kaki & $2 B-B$ \\
\hline Days & \multicolumn{2}{|c|}{ no. } & \multicolumn{2}{|c|}{$\mathrm{cm}$} & \multicolumn{2}{|c|}{$d m$} & \multicolumn{2}{|c|}{ no. } & \multicolumn{2}{|c|}{$\mathrm{cm}$} & \multicolumn{2}{|c|}{$d m$} \\
\hline 14 & $12.9 \mathrm{a}$ & 9.1 a & $21.6 \mathrm{a}$ & $15.3 \mathrm{a}$ & $29.8 \mathrm{bc}$ & $21.9 \mathrm{a}$ & $12.4 \mathrm{a}$ & $9.8 \mathrm{a}$ & $22.6 \mathrm{a}$ & $15.1 \mathrm{a}$ & $28.0 \mathrm{a}$ & $18.6 \mathrm{a}$ \\
\hline 21 & $11.8 \mathrm{a}$ & $10.3 \mathrm{a}$ & $22.3 \mathrm{a}$ & $14.7 \mathrm{ab}$ & $30.3 \mathrm{bc}$ & $21.4 \mathrm{ab}$ & $12.3 \mathrm{a}$ & $10.6 \mathrm{a}$ & $19.8 \mathrm{~b}$ & $15.1 \mathrm{a}$ & $27.3 \mathrm{a}$ & $18.5 \mathrm{a}$ \\
\hline 28 & $13.9 \mathrm{ab}$ & $11.0 \mathrm{a}$ & $22.5 \mathrm{a}$ & $14.5 \mathrm{ab}$ & $30.7 \mathrm{ab}$ & $20.7 \mathrm{ab}$ & $13.1 \mathrm{a}$ & $13.1 \mathrm{~b}$ & $19.6 \mathrm{~b}$ & $13.5 \mathrm{~b}$ & $27.8 \mathrm{a}$ & $17.9 \mathrm{a}$ \\
\hline 35 & $15.9 \mathrm{bc}$ & $14.3 \mathrm{~b}$ & $23.2 \mathrm{a}$ & $14.6 \mathrm{ab}$ & $31.2 \mathrm{a}$ & $20.8 \mathrm{ab}$ & $13.6 \mathrm{a}$ & $13.1 \mathrm{~b}$ & $18.7 \mathrm{~b}$ & $12.7 \mathrm{bc}$ & $26.7 \mathrm{ab}$ & $16.9 \mathrm{~b}$ \\
\hline 42 & $16.5 \mathrm{bc}$ & $17.0 \mathrm{c}$ & $22.5 \mathrm{a}$ & $13.7 \mathrm{~b}$ & $30.5 \mathrm{ab}$ & $20.5 \mathrm{bc}$ & $14.3 \mathrm{a}$ & $13.9 \mathrm{~b}$ & $18.3 \mathrm{~b}$ & $11.7 \mathrm{c}$ & $27.6 \mathrm{a}$ & $16.8 \mathrm{~b}$ \\
\hline Full & $17.9 \mathrm{c}$ & $20.0 \mathrm{~d}$ & $17.9 \mathrm{~b}$ & $11.9 \mathrm{c}$ & $28.6 \mathrm{c}$ & $19.4 \mathrm{c}$ & $14.5 \mathrm{a}$ & $12.2 \mathrm{~b}$ & $11.5 \mathrm{c}$ & $7.4 \mathrm{~d}$ & $25.9 \mathrm{~b}$ & $16.7 \mathrm{~b}$ \\
\hline season & & & & & & & & & & & & \\
\hline
\end{tabular}

${ }^{1}$ Measurements were taken after the last harvest. Means are based on 12 measurements each. Means are separated using Duncan's New Multiple Range Test (DNMRT) at $\mathrm{P}=0.05$. Means in the same column followed by common lower case letters do not differ statistically. 


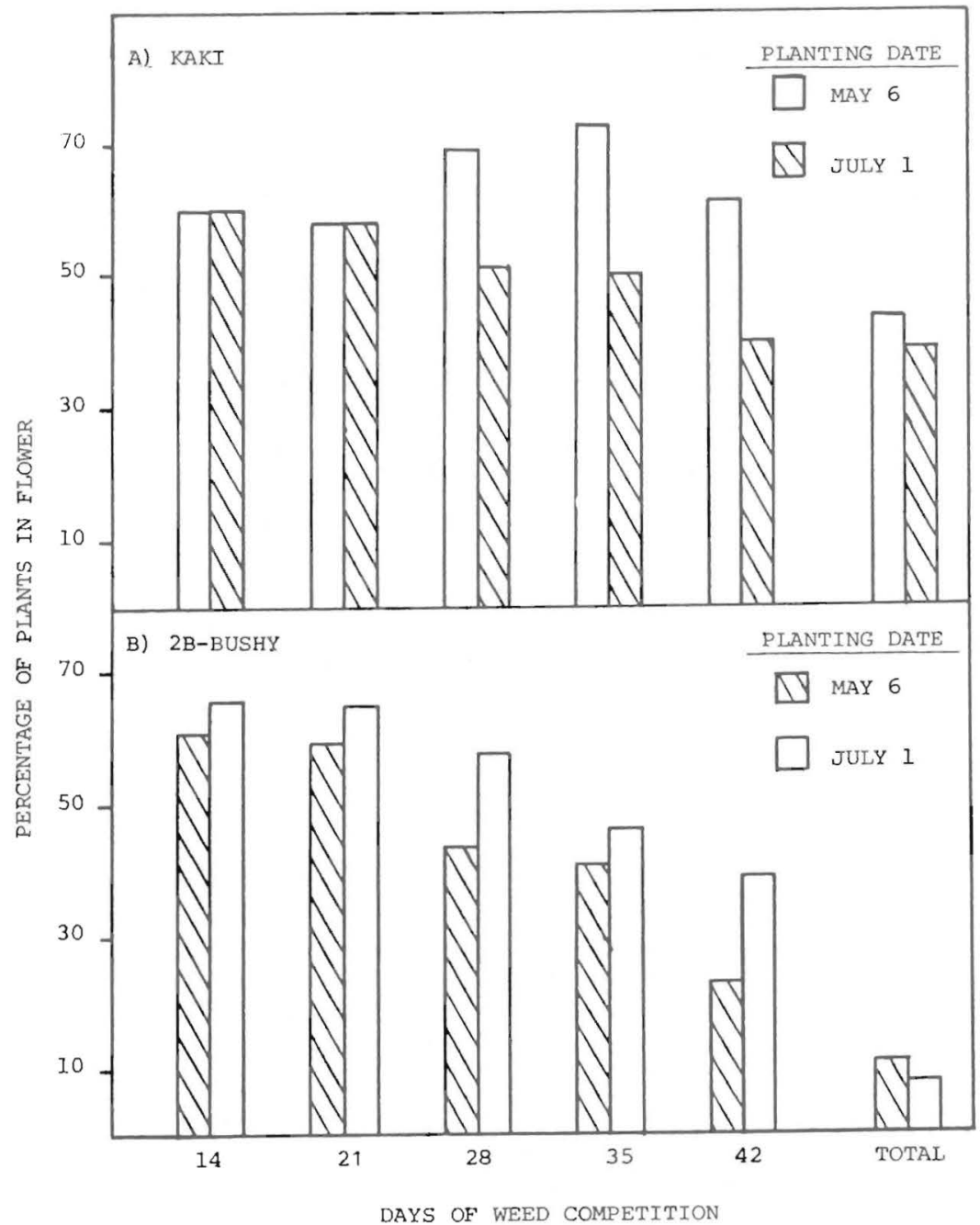

FIG. 3.-Influence of the period of weed competition on the flowering of Kaki (A) and 2B-Bushy (B) pigeon peas in two planting seasons in Juana Diaz, Puerto Rico.

the July planting stimulated greater initial growth in both cultivars, the May planting resulted in taller plants at harvest (table 4).

\section{CROP YIELD}

Weed development was not strictly associated with the yield of pigeon peas in that greater weed development was shown in the May planting, but earlier weed losses were found for the July planting (tables 1 and 5 and fig. 4). Nevertheless, increasing the period of early competition was 
TABLE 5.-Duration of early weed competition and losses in fresh pod and seed weight in Kaki pigeon peas in two planting seasons in Juana Diaz, Puerto Rico

\begin{tabular}{|c|c|c|c|c|c|c|}
\hline \multirow{3}{*}{$\begin{array}{c}\text { Duration } \\
\text { of weed } \\
\text { competition }\end{array}$} & \multicolumn{6}{|c|}{ Planting date } \\
\hline & \multicolumn{3}{|c|}{ May 6} & \multicolumn{3}{|c|}{ July 1} \\
\hline & $\begin{array}{l}\text { Fresh pod } \\
\text { and seed } \\
\text { yield }\end{array}$ & Loss & Loss & $\begin{array}{l}\text { Fresh pod } \\
\text { and seed } \\
\text { yield }\end{array}$ & Loss & Loss \\
\hline Days & $\mathrm{kg} / \mathrm{ha}$ & $\mathrm{kg} / \mathrm{ha}$ & $\$ / h a$ & $k g / h a$ & $\mathrm{~kg} / \mathrm{ha}$ & $\$ / h a$ \\
\hline 14 & 7,775 & - & - & 7,347 & - & - \\
\hline 21 & 7,862 & - & - & 7,307 & - & - \\
\hline 28 & 7,780 & - & - & 7,061 & 286 & 189 \\
\hline 35 & 7,086 & 786 & 519 & 6,763 & 584 & 385 \\
\hline 42 & 6,930 & 932 & 615 & 5,835 & 1,512 & 998 \\
\hline Full season & 4,936 & 2,926 & 1,931 & 5,966 & 1,381 & 911 \\
\hline
\end{tabular}

${ }^{1}$ Losses were calculated by using a price of $\$ 0.66$ per kilogram of fresh pigeon pea pods and seeds. Cost of weed control was not deducted from the loss figure.

TABLE 6.-Duration of early weed competition and losses in fresh pod and seed weight in $2 B$-Bushy pigeon peas in two planting seasons in Juana Diaz, Puerto Rico

\begin{tabular}{|c|c|c|c|c|c|c|}
\hline \multirow{4}{*}{$\begin{array}{c}\begin{array}{c}\text { Duration } \\
\text { of weed } \\
\text { competition }\end{array} \\
\text { Days }\end{array}$} & \multicolumn{6}{|c|}{ Planting date } \\
\hline & \multicolumn{3}{|c|}{ May 6} & \multicolumn{3}{|c|}{ July 1} \\
\hline & \multirow{2}{*}{$\begin{array}{c}\begin{array}{c}\text { Fresh pod } \\
\text { and seed } \\
\text { yield }\end{array} \\
\mathrm{kg} / \mathrm{ha}\end{array}$} & \multicolumn{2}{|c|}{ Crop losses ${ }^{1}$} & \multirow{2}{*}{$\begin{array}{c}\text { Fresh pod } \\
\text { and seed } \\
\text { yield }\end{array}$} & \multicolumn{2}{|c|}{ Crop losses } \\
\hline & & $\mathrm{kg} / \mathrm{ha}$ & $\$ / h a$ & & $\mathrm{~kg} / \mathrm{ha}$ & $\$ / h a$ \\
\hline 14 & 7,290 & $-^{2}$ & - & 6,725 & - & - \\
\hline 21. & 7,311 & - & - & 6,587 & 138 & 91.08 \\
\hline 28 & 6,929 & 382 & 252.12 & 6,530 & 195 & 128.70 \\
\hline 35 & 6,502 & 809 & 533.94 & 6,044 & 681 & 449.46 \\
\hline 42 & 5,827 & 1,484 & 979.44 & 5,576 & 1,149 & 758.34 \\
\hline Full season & 4,086 & 3,225 & $2,128.50$ & 4,917 & 1,808 & $1,193.28$ \\
\hline
\end{tabular}

${ }^{1}$ Losses were calculated by using a price of $\$ 0.66$ per kilogram of fresh pigeon pea pods with seeds. Cost of weed control was not deducted from the loss figure.

${ }^{2}$ Blanks indicate no observable economic loss.

associated with lower yield of both cultivars in both plantings. Kaki yielded more than 2B-Bushy in all cases, and appeared to be slightly more tolerant to weed competition.

\section{DISCUSSION}

Knowing the minimum level of pest activity which results in economic losses to crops is important for exercising efficient pest control. When minimum thresholds are not known, control measures may be exercised when they are not warranted, or control measures may not be taken when in fact they should be. Our objective was to determine pigeon pea 
VOL. LXIX, NO. 2, APRIL, 1985

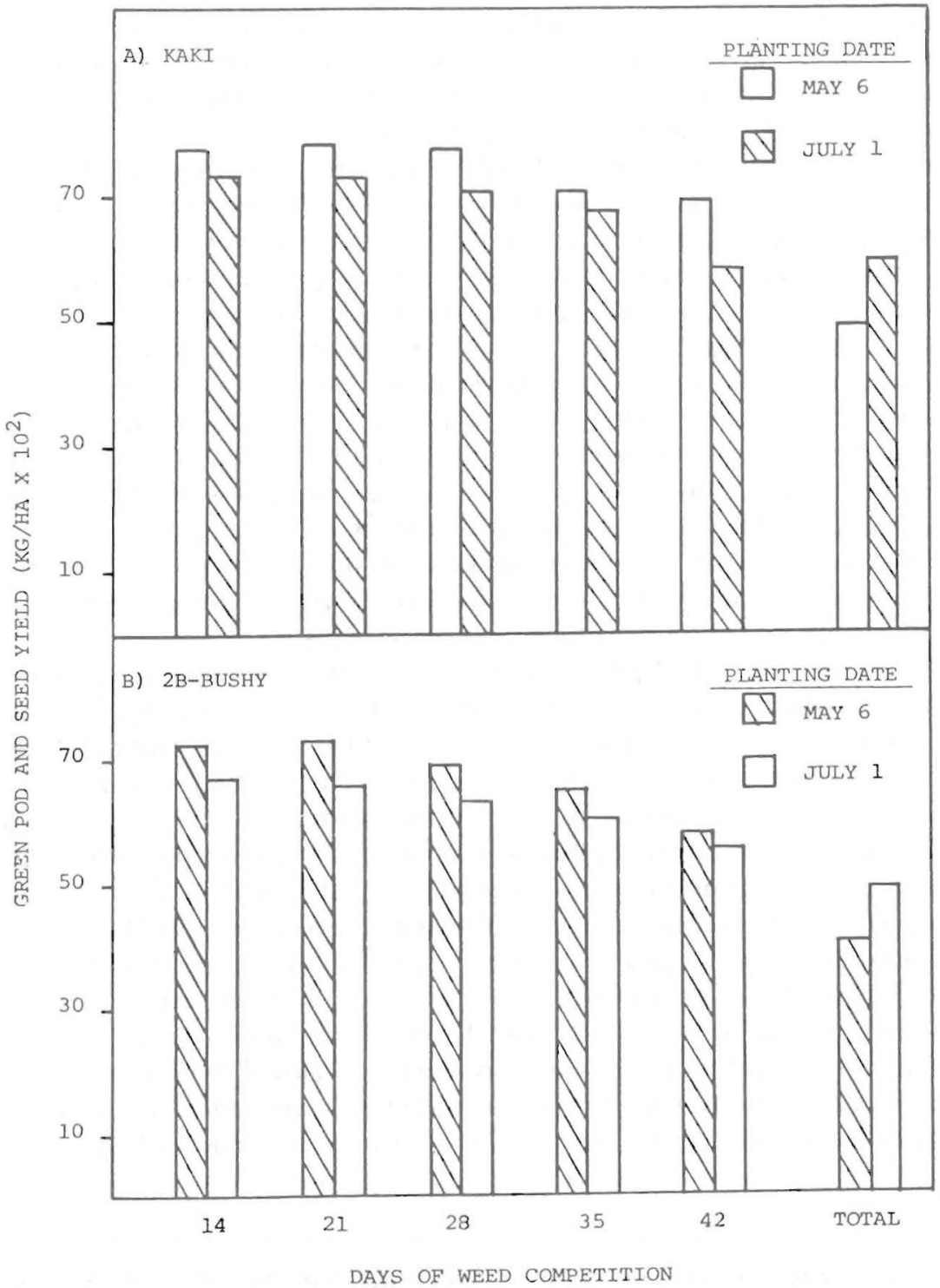

FIG. 4.- Influence of weed competition period on the green pod and seed yield of Kaki (A) and 2B-Bushy (B) pigeon peas in two planting seasons in Juana Diaz, Puerto Rico.

losses from weed competition on the south coast of Puerto Rico and the threshold of early weed competition before economic losses were evident.

Weed-crop competition may be viewed as an interaction of weeds with crop plants as influenced by the environment. Changes of any of these 
components can result in fluctuating weed competition levels and changes in crop losses. To consider the importance of these factors crop arrangements and densities, periods of weed competition, planting seasons, and crop cultivars were varied in our experiments.

Photoperiod during crop development appeared to have more influence on crop losses than any other environmental factor in our studies. Yield from pigeon peas planted in July was lower than that from the May planting. Economic losses from early weed competition occurred earlier in the second planting when earlier morphological development in pigeon peas occurred. Weed intensity and development was related to the precipitation level and was greater during the first planting. When developmental stages lasted longer as in the first cropping season, weed losses from full season weed competition were greater. The extent and time of weed induced losses in pigeon peas is closely related to the physiological and morphological development of the crop as influenced by the environment. Photoperiod was the only environmental factor which could be clearly related to differences in pigeon pea growth, yield, and weed losses between the two growing seasons.

Period of early weed presence was the most important weed-related factor in relation to crop growth and yield. The relationship between period of weed presence and crop loss varied between the two plantings and among the two crop cultivars. Kaki tolerated 28 days of early weed competition without losses in the first planting; however, in the July planting losses were found after only 21 days of early weed competition. Under the same conditions, losses were found at 21 and 14 days of early competition for the May and July plantings, respectively, in 2B-Bushy.

These findings suggest that weed removal can be most efficiently exercised at 20 to 30 days after crop emergence. Farmers may opt for 30 days in long-day plantings and when Kaki is grown and a 20-day interval in short-day plantings and when $2 \mathrm{~B}$-Bushy is used. Preemergence herbicides with activity for at least 20 to 30 days are needed for efficient control of weeds in pigeon peas on the south coast of Puerto Rico.

\section{RESUMEN}

Las cultivares de gandul Kaki y 2B-Bushy se sembraron en dos épocas diferentes y espaciadas en cuatro densidades. Se determinó la infuencia de seis intervalos de competencia con malezas en el crecimiento, desarrollo y rendimiento en la zona sur de Puerto Rico.

Durante las dos épocas de siembra las malezas predominantes fueron Cleome gynandra, Echinocloa colona, Amaranthus dubius, Leptocholoa filiformis y Digitaria sanguinalis.

Durante los primeros 40 días después de los grandules emerger pre- 
dominaron C. gynandra y C. colona. Posteriormente predominaron $L$. filiformis, $D$. sanguinalis y $A$. dubius.

La competencia de las malezas con el gandul disminuyó el crecimiento inicial, retrasó la diferenciación morfológica y afectó la floración en ambas cultivares. El eliminar las malezas antes de los 21 ó 28 días después de brotar el gandul propició una recuperación de las plantas y fue una medida preventiva para evitar pérdidas en el rendimiento final. La época de desyerbo para eliminar las malezas antes que causaran pérdidas al cultivo varió entre variedades y épocas de siembra. En la siembra de mayo, los rendimientos de las dos cultivares disminuyeron luego de los 28 y 21 días de competencia de las malezas en la Kaki y la 2B-Bushy, respectivamente. Sin embargo, en la siembra de julio las pérdidas en rendimiento causadas por la competencia de malezas se registraron después de los 21 y 14 días en las dos cultivares, respectivamente. No se encontró diferencia en el número total de malezas en ninguna de las cultivares ni entre las diferentes densidades de siembra en ninguna de las épocas de siembra. La cantidad de malezas fue mayor en la primera época en comparación con la de la segunda.

Los fotoperíodos cortos en la segunda época de siembra aceleraron el desarrollo vegetativo, redujeron el ciclo total y el rendimiento de ambas cultivares. También se encontró que al sembrar en épocas de fotoperíodos más cortos, los rendimientos se afectaron más temprano por causa de la competencia temprana de las malezas. 